\title{
PENGEMBANGAN MEDIA PEMBELAJARAN INTERAKTIF PADA MATA PELAJARAN SENI BUDAYA
}

\author{
Rouli Simanjuntak ${ }^{1}$, Abdul Hamid K. ${ }^{2}$ \\ Teknologi Pendidikan Pascasarjana Universitas Negeri Medan \\ Rouli_simanjuntak@yahoo.com ${ }^{1}$
}

\begin{abstract}
Abstrak: Tujuan studi penelitian dan pengembangan untuk (1) menghasilkan Media Interaktif yang sesuai untuk digunakan Mata Pelajaran Seni Budaya, (2) untuk mengetahui validitas para ahli dan Siswa terhadap Media Interaktif pada Mata Pelajaran Seni Budaya, dan (3) mengetahui efektivitas penggunaan Media Interaktif ini.Penelitian ini di adaptasi serta dimodifikasi dari model desain penelitian dan pengembangan menurut Borg \& Gall dan model pengembangan Dick and Carey. Hasil penelitian dan pengembangan menunjukkan bahwa: (1) produk Media Pembelajaran Interaktif Mata Pelajaran Seni Budaya dikemas dalam bentuk CD, (2) validasi para ahli secara umum menyatakan kualitas produk media pembelajaran interaktif ini termasuk dalam kriteria sangat baik dari rentang skor 1-5. (3) pengujian hipotesis produk Media Interaktif ini dinyatakan efektif digunakan untuk pembelajaran Seni budaya dimana terdapat perbedaan yang signifikan antara hasil belajar siswa sebelum dan sesudah diberikan media Pembelajaran Interaktif. Hasil pengolahan data dengan menggunakan uji $t$ diperoleh harga $t_{\text {hitung }}$ seharga 1,71 lebih besar dari $t_{\text {tabel }}$ seharga 1,66 maka dapat dinyatakan bahwa Media Pembelajran Interaktif Seni Budaya telah teruji efektif.
\end{abstract}

\section{Kata Kunci: media pembelajaran interaktif pada mata pelajaran seni budaya}

\begin{abstract}
The purpose of the research study and development for (1) generating an Interactive Media is suitable for use Subjects Arts and Culture, (2) to determine the validity of the experts and students of the Interactive Media in Subjects Arts and Culture, and (3) determine the effectiveness of using Media interactive ini.Penelitian is adapted and modified from the design model research and development according to Borg \& Gall and Dick and Carey model of development. Research and development results show that: (1) the product of Interactive Learning Media Arts Subjects packaged in a $\mathrm{CD},(2)$ validation of experts is publicly stating the product quality interactive learning media is included in the criteria very well out of the range of scores 1-5. (3) The hypothesis testing products Interactive Media was declared effectively used for art learning culture where there are significant differences between student learning outcomes before and after media Interactive Learning. The results of data processing by using the $t$ test obtained for the price of $1.71 \mathrm{t}$ is greater than $\mathrm{t}$ table for 1.66 it can be stated that pembelajran Interactive Media Arts and Culture has been proven effective.
\end{abstract}

Keywords: media interactive learning on the subjects of art and culture

\section{PENDAHULUAN}

Perkembangan teknologi informasi beberapa tahun belakangan ini berkembang dengan kecepatan yang sangat tinggi, sehingga dengan pekembangan ini telah mengubah paradigma masyarakat dalam mencari dan mendapatkan informasi, yang tidak lagi terbatas pada informasi surat kabar, audio visual, dan elektronik, tetapi juga sumber-sumber informasi lainnya yang salah satu diantaranya melalui jaringan internet. Perkembangan ilmu pengetahuan dan teknologi serta perubahan masyarakat yang sangat cepat mengharuskan para guru/ dosen untuk selalu mengikuti perkembangan serta persyaratan- persyaratan baru dalam keahlianya (Hamid 2009:1).Salah satu bidang yang mendapat dampak yang cukup berarti dengan perkembangan teknologi ini adalah bidang pendidikan, dimana pada dasarnya pendidikan merupakan investasi yang paling utama bagi setiap bangsa yang sedang berkembang, yang giat membangun negaranya. Pembangunan hanya dapat dilakukan oleh manusia yang di persiapkan melalui pendidikan ( Nasution 2011:5).

Pendidikan merupakan suatu proses komunikasi dan informasi dari pendidik kepada peserta didik yang berisi informasi-informasi 
pendidikan, yang memiliki unsur-unsur pendidik sebagai sumber informasi, media sebagai sarana penyediaan ide, gagasan dan materi pendidikan serta peserta didik itu sendiri (Oetomo dan Priyogutomo,2004:15),keberhasilan

peningkatan mutu, sumber daya manusia melalui pendidikan, terkait dengan berbagai aspek, salah satunya menyangkut kemampuan guru dalam mendesain suatu proses pembelajaran. Oleh karena itu, guru harus bisa memproduksi serta memanfaatkan teknologi berupa media pembelajaran agar dapat digunakan dalam proses pembelajaran sehingga perencanaan pembelajaran tidak lagi konvensional. Proses yang digunakan adalah proses pengembangan pembelajaran yang sistematik, dan bukan sekedar pendekatan intuitif.

Kosasih Djahiri (2007: 64) menyatakan bahwa" kualitas proses kegiatan belajar peserta didik amat menentukan kualitas dan kuantitas hasil kegiatan belajar peserta didik,proses kegiatan peserta didik akan lebih mudah,lancar, dan sukses dengan bantuan aneka media dan sumber belajar." Kemudian pemanfaatan media yang sangat terbatas oleh guru dalam proses pembelajaran.pemanfaatan media pembelajaran oleh guru agar indikator -indikator yang diharapkan dapat tercapai.ketercapaian tersebut dapat diketahui dengan adanya perubahan perilaku baik pada aspek kognitif, afektif, dan psikomotor.berkaitan dengan hal ini, guru hendaknya memberikan kesempatan pada peserta didik untuk mengaktualisaikan dirinya secara penuh dalam hal pembentukan perilakunya.oleh karena itu, sekolah dan lembaga pendidikan harus memperhatikan ketersediaan media pembelajaran juga pemanfaatanya oleh guru dalam proses pembelajaran.

Dalam proses pembelajaran terdapat tiga komponen yang saling berhubungan, yaitu : (1) pembelajar (dosen, guru, instruktur dan tutor) yang berfungsi sebagai komunikator, (2) pebelajar (mahasiswa dan siswa ) yang berperan sebagai komunikan, dan (3) bahan ajar yang merupakan pesan yang akan disampaikan kepada pebelajar untuk dipelajari (Situmorang, 2009:25).

Menurut Handoyo (2003: 31) Multimedia merupakan penyajian informasi yang berupa teks, gambar, dan suara secara bersama sehingga menjadi efektif dan efesien. Multimedia interaktif merupakan sebuah teknologi baru dengan potensi yang sangat besar untuk mengubah cara belajar, cara untuk mendapatkan informasi dan cara untuk menghibur.presentasi multimedia dapat Menggunakan beberapa macam teks ,chart, audio,video, animasi, simulasi atau foto.bila macam- macam komponen tersebut digabungkan secara interaktif,maka akan menghasilkan suatu pembelajaran yang efektif dan efesien.

Sutopo (2003: 54) mejelaskan perangkat lunak ini, merupakan sebuah program aplikasi standar authoring tool professional yang dikeluarkan oleh perusahaan internasional macromedia yang digunakan membuat animasi vector dan bitmap untuk keperluan pembangunan situs web, banner, tombol, animasi meni interaktif, interaktif form isian, ecard, screen sever dan pembuatan situs web atau pembuatan apilkasi web lainya. Dengan beberapa kemudahan itulah $A F B$ CS6 mendukung dalam penerapanya sebagai pengembang media pembelajaran berbentuk media interaktif..

Belajar adalah perubahan seluruh tingkah laku individu secara bertahap yang relatif menetap sebagai hasil pengalaman dan Interaksi dengan lingkungan yang melibatkan proses kognitif. Pada hakikatnya belajar adalah perubahan tingkah laku Abu Ahmadi (2003: 125). Perubahan tingkah laku sebagai hasil belajar ditunjukkan dengan berbagai aspek seperti perubahan pengetahuan, pemahaman, persepsi, motivasi, dan gabungan dari aspekaspek tersebut. Menurut Winkel (2007) belajar adalah suatu aktifitas mental atau psikis yang berlangsung dalam interaksi aktif dengan lingkungan, yang menghasilkan sejumlah perubahan dalam pengetahuan-pemahaman, keterampilan dan nilai sikap. Perubahan itu bersifat relatif konstan dan berbekas.belajar merupakan proses interaksi peserta didik dengan pendidik dan sumber belajar pada suatu lingkungan belajar. belajar merupakan bentuan yang diberikan pendidik agar dapat terjadi proses perolehan ilmu dan pengetahuan, penguasaan kemahiran dan tabiat, serta pembentukan sikap dan kepercayaan pada peserta didik.. Berkaitan dengan belajar, menurut Wardani, dkk, (2005: 217) mengemukakan, belajar adalah suatu proses yang dilakukan oleh individu untuk memperoleh perubahan perilaku yang baru secara keseluruhan sebagai hasil dari pengalaman individu itu sendiri dalam interaksi dengan lingkungan. 
Sedangkan pembelajaran menurut Sujdana yang di kutip Sugihartono, dkk. (2007: 80) merupakan setiap upaya yang dilakukan dengan sengaja oleh pendidik yang dapat menyebabkan peserta didik melakukan kegiatan belajar. Menurut Bruner (dalam Sudjana, 2001:58), belajar yang terbaik haruslah merupakan proses berpikir, dan berpikir pada hakikatnya merupakan proses kognitif, sehingga manusia membedakan, memilih, dan menentukan objek serta kemampuan untuk mengkonstruksi kembali informasi yang telah diterima. Lebih jauh lagi, Sadiman (1984: 71) mengatakan belajar adalah suatu proses yang kompleks yang terjadi pada semua orang dan berlangsung seumur hidup, sejak dia masih bayi hingga ke liang lahat nanti. Salah satu pertanda bahwa seorang telah belajar sesuatu adalah adanya perubahan tingkah laku dalam dirinya. Perubahan tingkah laku tersebut menyangkut baik perubahan yang bersifat pengetahuan (kognitif) dan keterampilan (psikomotor) maupun nilai dan sikap (afektif).

Hasil belajar adalah semua efek yang dapat di jadikan sebagai indikator tentang nilai dari penggunaan metode pembelajaran di bawah kondisi yang berbeda. Hasil belajar menurut Bloom yang direvisi Anderson (2001: 27) menyatakan, hasil belajar dibagi dalam tiga kawasan yaitu kognitif, afektif, dan psikomotor. Kawasan kognitif terdiri dari enam jenis perilaku yaitu: (1) ingatan, mencakup kemampuan mengingat tentang hal yang teah dipelajari dan tersimpan dalam ingatan, pengetahuan tersebut mencakup kemampuan fakta, pengetahuan konsep, pengetahuan prosedur, dan pengetahuan metakognitif, (2) pemahaman, mencakup kemampuan menangkap arti dan makna dari pesan, pembicaraan, tulisan dan grafik, berkaitan dengan pengetahuan fakta dan pengetahuan konsep, (3) penerapan, mencakup kemampuan menerapkan atau menggunakan prosedur untuk mengahadpi situasi yang baru, berkaitan dengan pengetahuan konsep, (5) evaluasi, mencakup kemampuan membentuk pendapat tentang beberapa hal berdasarkan kriteria dan standar teretntu, berkaitan dengan pengetahuan prosedural dan pengetahuan metakognitif, dan (6) kreativitas, mencakup kemampuan menggabungkan beberapa bagian menjadi suatu bentuk yang koheren atau berfungsi secara menyeluruh, mengorganisaikan bagian-bagian menjadi sebuah pola atau struktur yang baru, berkaitan dengan pengetahuan konsep.
Menurut Reigeluth (1983) hasil pembelajaran harus memiliki efektivitas, efisiensi dan daya tarik. Efektifitas diukur dari tingkat pencapaian hasil belajar yang diperoleh oleh peserta didik, baik secara kualitas maupun kuantitas. Secara kualitas belajar menunjukkan kebermaknaan isi bahasa yang dipelajari dalam kehidupan sehari-hari, sedangkan kuantitas menunjukkan jumlah variasi hasil belajar yang dapat dicapai oleh siswa. Efisiensi diukur berdasarkan waktu yang dibutuhkan siswa untuk belajar, dalam arti semakin sedikit waktu yang dibutuhkan siswa untuk memahami isi materi pelajaran, maka semakin efisien hasil belajar yang diperoleh. Sedangkan daya tarik diukur dari ada tidaknya kecenderungan siswa termotivasi untuk belajar lebih lanjut dalam arti mengembangkan wawasan berdasarkan hasil belajar yang telah diperoleh.

Romizowski (1981: 79) menyatakan bahwa hasil belajar diperoleh dalam bentuk pengetahuan dan keterampilan. Pengetahuan dikelompokkan pada empat kategori yaitu, (1) fakta, merupakan pengetahuan tentang objek, peristiwa atau manusia, (2) konsep, merupakan pengetahuan tentang seperangkat objek kongkrit atau definisi, (3) prosedur, merupkan pengetahuan tentang tindakan demi tindakan yang bersifat linear dalam mencapai suatu tujuan, dan (4) prinsip, merupakan pernyataan mengenai hubungan dari dua konsep atau lebih. Sedangkan hasil belajar dalam bentuk keterampilan juga dikelompokkan dalam empat kategori, yaitu, (1) keterampilan kognitif, merupakan keterampilan seseorang dalam menggunakan pikiran untuk mengambil keputusan atau memecahkan masalah, (2) akting, yaitu keterampilan fisik atau teknik seperti olahraga atau terampil dalam mengerjakan sesuatu, (3) reaksi, merupakan keterampilan bereaksi terhadap suatu situasi dalam arti nilai-nilai emosi dan perasaan dengan orang lain untuk mencapai suatu tujuan seperti komunikasi,

Standar Kompetensi Mata Pelajaran Seni dan Budaya dikelompokkan dalam: (1) Seni Rupa; (2) Seni Musik; (3) Seni Tari, dan (4) Seni Teater. Siswa boleh memilih satu atau dua dari cabang seni tersebut. Mata pelajaran seni budaya bertujuan agar peserta didik memiliki kemampuan: (1) Memahami konsep dan pentingnya seni budaya,(2) Menampilkan sikap apresiasi terhadap seni budaya (3) Menampilkan kreativitas melalui seni budaya, ( 4) Menampilkan peran serta dalam seni budaya 
dalam tingkat lokal, regional maupun global. Aspek Penilaian dalam mata pelajaran ini dikelompokkan dalam aspek apresiasi dan Kreasi. Konsepsi dilebur ke dalam aspek apresiasi dan/atau kreasi sesuai dengan tuntutan kompetensinya. Nilai KD (kompetensi dasar) konsepsi yang terkait dengan apresiasi masuk ke dalam aspek penilaian apresiasi, sedangkan nilai KD konsepsi yang terkait dengan kreasi masuk ke dalam aspek penilaian kreasi. Jadi masingmasing cabang seni memiliki nilai apresiasi dan kreasi. Hal ini untuk mencegah bentuk penilaian yang teoritis pada mata pelajaran seni budaya.

Seni Budaya merupakan penjelmaan rasa indah yang terkandung dalam jiwa orang yang di lahirkan dengan perantaraan alat- alat komunikasi ke dalam bentuk yang dapat di tangkap oleh indra pendengar( seni suara) ,penglihatan ( seni rupa), atau dilahirkan dengan perantaraan gerak ( seni tari,drama).seni dapat pula dikatakan sebagai ungkapan atau kesankesan yang diterima oleh panca indera, jiwa, dan perasaan manusia.seni lahir dari proses peralihan gagasan atau ide manusia kedalam bentuk ungkapan yang lebih nyata. Pendidikan Seni budaya selalu hadir dalam kurikulum sekolah, karena seni merupakan bagian dari kebutuhan manusia. Sebagaimana Pratt (1980: 54) mengatakan, bahwa dalam menyusun kurikulum sebaiknya melibatkan lima kebutuhan manusia (human needs), yakni "need for selfactualization, needs for meaning, social needs, aesthetic needs, and survival needs". Pernyataan Pratt tersebut menunjukkan bahwa aesthetic needs dipandang sebagai bagian yang esensial dari kurikulum sekolah, sehingga penting dilaksanakan di sekolah-sekolah.

Menurut Pakpahan (1996:85) Gambar bentuk merupakan hasil upaya memindahkan imaji benda dengan segenap atribut dan keadaan sekelilingnya ke dalam media gambar kertas/kanvas, setepat mungkin seperti aslinya. Dalam hal ini teknik, fasilitas, media dan keterampilan menggambar sangat berpengaruh terhadap hasil akhir yang berupa gambar bentuk. Disamping itu, pengamatan yang cermat dan rinci akan sangat menunjang peniruan/imitasi tersebut. Dalam gambar bentuk dapat dikelompokkan menjadi gambar hitam putih dan gambar berwarna. Alat atau media yang dipakai dalam gambar bentuk dapat dipilah menjadi: a) Alat/media kering, yaitu media yang dalam penggunaannya langsung tanpa harus dibubuhkan/ dicampur dengan bahan yang berifat basah/cair (contohnya pensil, krayon, pastel ). b) Alat / media basah yaitu media yang dalam penggunaannya harus dibubuhi /dicampur dengan bahan yang bersifat basah ( contohnya tinta, cat air, cat poster, cat minyak). Dalam menggambar bentuk diperlukan komponen yang harus dipenuhi yaitu: Keseimbangan, Komposisi,Proporsi.Menurut Sugianto (dalam Nur Hidayah, 2007: 7) Menggambar bentuk memiliki pengertian memindah objek alami tiga dimensi ke dalam bidang datar dua dimensi dengan ciri dan sifat yang sama, ketepatan bentuk, ketepatan pandangan dan ketepatan bayangan.

Pengertian menggambar bentuk menurut Hanung Rosifah (2007: 3) adalah menggambar secara fisioplastis artinya menggambar benda dengan cara menangkap bentuk fisik benda tersebut. Atau dengan kata lain menggambar yang seakan-akan memindahkan benda ke dalam gambar tanpa adanya perubahan perubahan. Jadi dalam gambar bentuk, objek harus kita hadapi dan kemiripan gambar dengan objek merupakan kunci keberhasilan. Jadi menggambar adalah membuat goresan yang merupakan wujud tampilan yang dihadirkan oleh seseorang untuk mengekpresikan imaji tertentu dengan maksud untuk mengkomunikasikan terhadap orang lain.

Menurut Hanung Rosifah (2007: 5), keterampilan menggambar bentuk adalah ketika dalam menggambar memenuhi ketentuan pokok dalam proses pembelajaran yaitu: 1) ketetapan bentuk, yaitu menggambar sesuai objek yang digambar, ketetapan bentuk sangat diutamakan. 2) Ukuran perbandingan yang tepat/ proporsi, yaitu perbandingan antara benda satu dengan yang lain. 3) pembagian Bidang yaitu cara menempatkan benda-benda yang digambar ke dalam bidang gambar. Pembagian bidang yang baik bisa dilakukan dengan cara: ambil kertas karton yang dilubangi dengan skala kertas gambar yang digunakan. Setelah itu arahkan lubang kertas ke arah objek yang digambar, seperti halnya melihat dengan alat pptert melalui lensa. Amati betul-betul pengaturannya agar mendapat pengaturan bentuk yang baik. 4) Komposisi yaitu pengaturan benda-benda yang akan digambar agar kelihatan baik komposisinya dalam bidang gambar. 5) Terjemahan bahasa yaitu menterjemahkan dari bahan apa objek yang kita gambar, misalnya dari kayu, dari tanah liat atau dari bahan-bahan yang lainnya dan kita harus mampu menggambarkan bahan tersebut.

Dijabarkan juga oleh Djamarah (1995 : 136), Media adalah alat bantu apa saja yang 
dapat dijadikan sebagai penyalur pesan guna mencapai Tujuan pembelajaran".media pembelajaran adalah penyalur atau penghubung pesan ajar yang diadakan dan/ atau di ciptakan secara terencana oleh para guru atau pendidik( munadi: 2008: 5) Dr. Arief S. Sadiman, dkk. (2012: 6), Media adalah segala sesuatu yang dapat digunakan untuk menyalurkan pesan dari pengirim ke penerima sehingga dapat merangsang pikiran, perasaan, perhatian, dan minat serta perhatian siswa sedemikian rupa sehingga proses belajar terjadi. Dari pengertian tersebut berarti guru adalah orang yang menggunakan segala bentuk dan saluran untuk menyalurkan pesan/informasi, bukan berperan sebagai media juga. Sedangkan media sendiri digunakan guru untuk mengefektifkan dan mengefesiensikan proses pembelajaran itu sendiri. Pekerjaan mengajar tidak selalu harus diartikan sebagai kegiatan menyajikan materi pelajaran. Meskipun penyajian materi pelajaran memang merupakan bagian dari kegiatan pembelajaran, tetapi bukanlah satusatunya.Masih banyak cara lain yang dapat dilakukan guru untuk membuat siswa belajar. Media pembelajaran sebagai sumber belajar memiliki makna bahwa media dapat menggantikan fungsi guru dalam menyampaikan materi pembelajaran baik ranah kognitif maupun ranah psikomotor. Penggunaan media video pembelajaran yang dirancang dapat digabungkan menggunakan pendekatan siswa aktif seperti diskusi dan presentasi sehingga peran guru dalam pembelajaran tidak lebih dari fasilitator di dalam kelas. Peran yang seharusnya dilakukan guru adalah mengusahakan agar setiap siswa dapat berinteraksi secara aktif dengan berbagai sumber balajar yang ada.

Dalam pemilihan media yang paling tepat, Sadiman (2012: 84) mengemukakan beberapa prinsip yang harus di perhatikan yaitu ( 1) Prinsip efektifitas dan efesiensi adalah keberhasilan pembelajaran yang di ukur dari tingkat ketecapaian tujuan setelah pembelajaran selesai dilaksanakan. Jika semua tujuan pembelajaran telah tercapai maka pembelajaran disebut efektif, sedangkan efesiensi adalah tujuan pencapaian tujuan pembelajaran dengan menggunakan media, waktu dan sumber daya lain seminimal mungkin. Media yang telah memenuhi aspek efektifitas dan efesiensi ini tentunya akan meningkatkan ketertarikan siswa dalam belajar dan mendukung pencapaian tujuan pembelajaran. Materi yang disampaikan melalui media ini juga akan lebih mudah diserap anak didik (2) Prinsip relevan, relevansi ini ada dua macam yaitu relevansi kedalam dan relevansi keluar. Relevansi kedalam adalah pemilihan media pembelajaran yang mempertimbangkan kesesuaian dan sinkronisasi antara tujuan, isi, strategi dan evaluasi materi pembelajaran. Relevansi kedalam juga mempertimbangkan pesan guru, siswa, dan desain media yang akan digunakan dalam pembelajaran.Relevansi keluar adalah pemilihan media yang disesuaikan dengan kondisi perkembangan masyarakat . media yang dipilih disesuaikan dengan apa yang biasa digunakan masyarakat secara luas. media yang relevan secara internal dan ekternal ini akan meningkatkan fungsi dan manfaat media itu sendiri.(3) Prinsip produktifitas ,Produktifitas dalam pembelajaran dapat dipahami pencapaian tujuan pembelajaran secara optimal dengan menggunakan sumber daya yang ada, baik sumber daya manusia maupun sumber daya alam. Jika media yang digunakan bisa menghasilkan dan mencapai target dantujuan pembelajaran lebih bagus dan banyak maka media tersebut dikategorikan media produktif Semakin produktif media yang digunakan maka akan semakin cepat dan tepat tujuan pembelajaran yang terealisasikan.Disamping prinsip pemilihan

Media pembelajaran interaktif memiliki berbagai manfaat yang dapat menunjang proses pembelajaran. Menurut Kustiono (2010:9) Media pembelajaran interaktif memiliki manfaat dalam meningkatkan efektivitas proses pembelajaran yaitu: (a) Memungkinkan terjadinya interaksi langsung antara pengguna dan materi pembelajaran,(b) Proses pembelajaran dapat berlangsung secara individu sesuai dengan kemampuan siswa, (c) Dapat meningkatkan minat dan motivasi belajar siswa, (d) Dapat memberikan umpan balik terhadap respon siswa, (e) Dapat menciptakan proses belajar yang berkesinambungan.karakteristik dalam media pembelajaran interaktif adalah bahwa siswa tidak hanya memperhatikan penyajian atau objek, tetapi dipaksa untuk berinteraksi mengikuti pelajaran. Menurut miarso (2004: 465) paling sedikit ada tiga macam interaksi yang dapat diidentifikasi. Pada tingkat pertama, siswa berinteraksi pada sebuah program, misalnya mengisi blanko pada teks yang terprogram. Tingkat berikutnya siswa berinteraksi dengan mesin, misalnya mesin pembelajaran, simulator, laboratorium bahasa atau terminal computer. Bentuk ketiga media 
interaktif adalah yang mengatur interaksi antar siswa secara teratur tetapi tidak terprogram. Mengacu pada pendapat beberapa ahli,dapat diduga bahwa pengembangan media pembelajaran interaktif pada menggambar bentuk benda silindris merupakan upaya pemecahan pembelajaran gambar bentuk benda dengan teknologi computer yang semakin canggih melalui serangkaian proses desain, produksi, dan evaluasi. Kegiatanya bukan hanya mengembangkan produk pembelajaran secara terpisah tetapi menyangkut memdesain pembelajaranya dan pemanfaatanya.media pembelajaran yang tinggi akan dapat menghasilkan penguatan yang tinggi. Untuk menunjang agar media pembelajaran interaktif ini memiliki manfaat dalam meningkatkan efektivitas proses pembelajaran pada menggambar bentuk benda silindris diperlukan media pembelajaran interaktif yang tepat salah satu contohnya yaitu Adobe Flash Professional CS6

Sukmadinata (2010) menjelaskan "Apabila langkah-langkah tersebut diatas, diikuti dengan benar, diasumsikan menghasilkan suatu produk pembelajaran yang siap dipakai pada tingkat sekolah sehingga dapat di pertanggungjawabkan. Untuk menghasilkan produk media pembelajaran interaktif diperlukan perencanaan, perangcangan yang baik.dalam pengembangan media pembelajaran interaktif ini digunakan rancangan pembelajaran model Dick \& Carey.Dick \& Carey (2005:9) adalah salah satu contoh model yang berorientasi pada hasil, karena penerapan konsep-konsep dan prinsip-prinsip perancangannya akan menghasilkan bahan belajar mandiri. Komponen model Dick, Carey, dan Carey meliputi; pembelajar, pebelajar, materi, dan lingkungan. Demikian pula dilingkungan pendidikan non formal meliputi; warga belajar (pebelajar), tutor (pembelajar), materi, dan lingkungan pembelajaran (Ditjen PMPTK PNF, 2006). Semua berinteraksi dalam proses pembelajaran untuk mencapai tujuan yang telah ditetapkan. Bila melihat komponen bekerja dengan memuaskan atau tidak maka perlu mengembangkan format evaluasi (Dick, Carey, dan Carey, 2001). Jika dari hasil evaluasi menunjukkan unjuk kerja pebelajar tidak memuaskan maka komponen tersebut direvisi untuk mencapai kriteria efektif dalam mencapai tujuan pembelajaran.

Rumusan penelitian dan pengembangan ini adalah: (1) Apakah Media Interaktif yang sesuai untuk digunakan Mata Pelajaran Seni Budaya layak digunakan dalam proses pembelajaran seni budaya, (2) apakah media interaktif yang dikembangkan efektif dapat digunakan dalam proses pembelajaran seni budaya.

\section{METODE}

Penelitian di laksanakan di SMP Negeri 6 Pematangsiantar kelas VII. Model pengembangan dalam penelitian ini menggunakan model pengembangan Borg \& Gall (1983) yang di padu dengan model Dick and Carey (2005: 1) untuk merancang sistem pembelajaran.Menurut langkah-langkah pengembangan produk, model penelitian dan pengembangan ini lebih rasional dan lebih lengkap .Model ini dipilih karena sering digunakan untuk menggambarkan pendekatan sistematis untuk pengembangan instruksional. Selain itu, model ini dapat digunakan untuk berbagai macam bentuk pengembangan produk seperti model, strategi pembelajaran, metode pembelajaran, media dan bahan ajar. Oleh karena itu, model tersebut sesuai digunakan untuk penelitian pengembangan. untuk merancang sistem pembelajaran, dalam rangka menghasilkan media pembelajaran mata pelajaran seni budaya

Prosedur pengembangan memaparkan langkah- langkah prosedural yang ditempuh oleh pengembang dalam membuat produk.prosedur pengembangan secara tidak langsung akan memberi petunjuk bagaimana langkah prosedural yang dilalui sampai ke produk yang akan dispesifikasikan. Prosedur pengembangan yang ditempuh untuk menghasilkan produk pembelajaran berbasis macromedia flash dibagi menjadi 6 (enam) tahap, yaitu: (1) tahap pertama melakukan penelitian pendahuluan, tahap ini diawali dengan identifikasi kebutuhan pembelajaran dan menentukan standar kompetensi mata pelajaran, melakukan analisis pembelajaran, mengidentifikasi karakteristik dan perilaku awal siswa, menentukan kompetensi dasar serta indikator, menulis tes acuan patokan, mengembangkan materi pembelajaran, (2) tahap kedua pembuatan desain media. Pada tahap kedua ini diawali dengan pembuatan desain software, pembuatan naskah, pembuatan storyboard, pembuatan flowchart view, (3) tahap ketiga pengumpulan bahan, diawali dengan pengumpulan bahan pembuatan dan pengumpulan gambar animasi, perekaman dan 
pengumpulan audio, (4) tahap keempat membuat dan memproduksi Media Pembelajaran Berbasis macromedia flash, yang dilengkapi dengan petunjuk-petunjuk media seperti: petunjuk belajar, deskripsi singkat, kompetensi dasar, uraian materi, soal-soal latihan, yang terakhir sebagai penutup adalah rangkuman, (5) tahap kelima yaitu review atau uji ke lapangan dalam rangka evaluasi formatif dan revisi produk. Dan (6) uji keefektifan produk.Evaluasi formatif terus berlangsung selama proses pengembangan mulai dari tahap analisis, desain, produksi maupun implementasi sampai diperoleh hasil yang sesuai dengan tujuan yang telah ditetapkan

Kriterian software akan dikonversikan menjadi nilai dengan skala lima menggunakan skala Likert yang dianalisis secara deskriptif persentase dengan rumus sebagai berikut (Purwanto,2009: 112)

$$
\mathrm{X}=\frac{\text { Jumlahskoryangdiperoleh }}{\text { Jumlahskoridealseluruhitem }} \times 100 \%
$$

Dengan kriteria penilaian seperti yang tertulis pada Tabel berikut ini:

Tabel 1. Kriteria Penilaian

\begin{tabular}{|c|l|c|}
\hline Nilai & Kriteria & Persentase \\
\hline A & Sangat baik & $81 \% \leq \times \leq 100 \%$ \\
\hline B & Baik & $61 \% \leq \times<80 \%$ \\
\hline C & Sedang & $41 \% \leq \times<60 \%$ \\
\hline D & Kurang baik & $21 \% \leq \times<40 \%$ \\
\hline E & $\begin{array}{l}\text { Sangat } \\
\text { kurang baik }\end{array}$ & $0 \% \leq \times<20 \%$ \\
\hline
\end{tabular}

$X=$ Skor Empiris(Purwanto,2009:82)

Penelitian di laksanakan di SMP Negeri

6 Pematangsiantar.Populasi dalam penelitian ini adalah siswa kelas VII yang berjumlah 7 kelas (245 siswa) dari seluruh populasi ditentukan sampel sebanyak dua kelas, yaitu kelas VII -1 sebagai kelas kontrol dengan jumlah siswa sebanyak 30 orang dan kelas VII-2 sebagai kelas eksperimen sebanyak 30 orang.

Dalam penelitian ini data yang diperoleh adalah hasil belajar siswa dari kelas eksperimen dan kelas kontrol. Teknik analisis data yang digunakan adalah teknik deskriptif dan inferensial. Teknik deskriptif adalah statistik yang digunakan untuk menganalisis data dengan cara menggambarkan data yang telah terkumpul sebagaimana adanya tanpa bermaksud membuat kesimpulan yang berlaku untuk umum atau generalisasi. Misalnya penyajian data menggunakan tabel, grafik, diagram lingkaran, pictogram, perhitungan modus, median, mean, desil, persentil, rata-rata, standar defiasi, porsentasi, korelasi, dan regresi tanpa pengujian signifikasi. Dan teknik inferensial adalah teknik statistik untuk menganalisis data sampel data dan hasilnya diberlakukan untuk populasi. Suatu kesimpulan dari data sampel yang akan diberlakukan untuk populasi itu mempunyai peluang kesalahan dan kebenaran (kepercayaan). Langkah-langkah teknik analisa data sebagai berikut :

\section{Nilai Rata-rata}

Untuk menentukan nilai rata-rata digunakan rumus :

$$
\bar{x}=\sum x
$$

\section{Standar Deviasi}

Untuk menentukan Standar Deviasi digunakan rumus yaitu, $s=\sqrt{\frac{\sum(x i-\bar{x})^{2}}{n-1}}$ (Sudjana, 2005:93)

Dimana $: s=$ Standar Deviasi

$$
\begin{aligned}
& x i=\text { Harga data ke-i } \\
& n=\text { Jumlah Sempel }
\end{aligned}
$$

\section{Uji Normalitas}

Uji normalitas data menggunakan teknik Lilliefors (Sudjana, 2005: 466). Langkahlangkah yang digunakan adalah sebagai berikut:

a. Data hasil belajar $x_{1}, x_{2}, \ldots, \ldots, x_{n}$ dijadikan bilangan baku $\mathrm{z}_{1}, \mathrm{z}_{2}, \ldots, \ldots, \mathrm{z}_{\mathrm{n}}$ dengan menggunakan rumus : $Z_{I}=\frac{X 1-\bar{X}}{S}$

Dimana $: \bar{x}=$ Nilai rata-rata hitung

$$
\mathrm{S}=\text { Simpangan baku }
$$

b. Untuk tiap bilangan baku ini menggunakan daftar distribusi normal baku, kemudian dihitung peluang $\mathrm{F}\left(\mathrm{Z}_{1}\right)=\mathrm{P}\left(\mathrm{z} \leq \mathrm{Z}_{\mathrm{i}}\right)$

c. Menghitung proporsi $S \quad\left(\mathrm{z}_{\mathrm{i}}\right)=$ $\frac{\text { banyaknya } Z 1, Z 2, \ldots, \ldots, Z n \leq Z i}{n}$

d. Hitung selisih $\mathrm{F}\left(\mathrm{zi}_{\mathrm{i}}\right)-\mathrm{S}(\mathrm{zi})$ kemudian tentukan harga mutlaknya.

e. Menentukan harga terbesar dari selisih harga mutlak $\mathrm{F}\left(\mathrm{Z}_{\mathrm{i}}\right)-\mathrm{S}\left(\mathrm{zi}_{\mathrm{i}}\right)$ sebagai $\mathrm{L}_{\mathrm{o}}$. Untuk menerima atau menolak distribusi normal danpenelitian dapat dibandingkan $\mathrm{L}_{\text {hitung }}$ dengan nilai kritis $\mathrm{L}_{\text {tabel }}$ yang diambil dari daftar table uji lilliefors dengan taraf $a=$ $5 \%$.

Kriteria pengujian :

Jika $\mathrm{L}_{\text {hitung }}<\mathrm{L}_{\text {tabel }}$ maka sampel berdistribusi normal.

Jika $\mathrm{L}_{\text {hitung }}>\mathrm{L}_{\text {tabel }}$ maka sampel tidak berdistribusi normal.

\section{Uji Homogenitas}

Uji Homogenitas varians dihitung dengan besar menggunakan uji F yaitu : 
$F=\quad \frac{\text { Varians Terbesar }}{\text { Varians Terkecil }}$ atau $F=\frac{S 1^{2}}{S 2^{2}}$

Dimana: (Sudjana, 2005: 249)

$S_{l}^{2}=$ Varians dari kelompok yang lebih besar

$S_{2}^{2}=$ Varians dari kelompok kecil

Kriteria pengujian :

Jika $F_{\text {hitung }}<F_{\text {tabel }}$ maka sampel mempunyai varians yang sama.

Jika $F_{\text {hitung }} F_{\text {tabel }}$ maka sampel tidak mempunyai varians yang sama.

\section{Pengujian Hipotesis}

Hipotesis penelitian yang akan diuji adalah :

$\mathrm{H}_{\mathrm{o}}: \mu_{1}=\mu_{2}$

$\mathrm{H}_{\mathrm{a}}: \mu_{1}>\mu_{2}$

Keterangan :

$\mu_{1}$ :Rata-rata hasil belajar siswa yang diajar menggunakan media pembelajaran interaktif.

$\mu_{2}$ :Rata-rata hasil belajar siswa yang diajar dengan menggunakan Buku Teks.

$\mathrm{H}_{\mathrm{o}}$ : Tidak ada hasil perbedaaan hasil belajar seni budaya siswa yang diajar dengan menggunakan media pembelajaran interaktif berbasis macromedia flash lebih tinggi dan siswa yang diajar dengan menggunakan Buku Teks..

$\mathrm{H}_{\mathrm{a}}$ : Ada perbedaan hasil belajar seni budaya siswa yang diajar dengan menggunakan media pembelajaran interaktif berbasis macromedia flash lebih tinggi dari siswa yang diajar dengan menggunakan Buku Teks..

Untuk uji hipotesis digunakan rumus uji dua pihak :

$t=\frac{\bar{x}}{s \sqrt{\frac{1}{n 1}}}$
Dimana $\mathrm{S}$ adalah akar varians gabungan yang dihitung dengan rumus :

$S^{2}=\frac{(n 1-1) S 1^{2}+(n 2-1) S 2^{2}}{n 1+n 2-2}$ Dimana $S=\sqrt{S^{2}}$

Dimana :

$t=$ Harga perhitungan

$\mathrm{n}_{1}=$ Jumlah sampel kelas eksperime

$\overline{x_{1}}=$ Skor rata-rata kelas eksperimen

$\mathrm{n}_{2}=$ Jumlah sampel kelas control

$x_{2}=$ Skor rata-rata kelas control

$S=$ Varians gabungan

$S 1^{2}=$ Varians kel. kelas eksperimen

$S 2^{2}=$ Varians kel. kelas control

Kriteria pengujian terima Ha jika $t_{\text {hitung }}>t_{\text {tabel }}$ yang didapat dari daftar distribusi dengan $\mathrm{dk}=$ (n-1) dan taraf $\alpha=5 \%$. Untuk melihat nilai keefektifan media pembelajaran interaktif yang dieksperimen digunakan rumus perhitungan efektifitas berikut (Purwanto 2004:112) :

$$
\mathrm{X}=\frac{\text { Jumlah skor yang diperoleh }}{\text { Jumlah skor ideal seluruh item }} \times 100
$$

\section{HASIL DAN PEMBAHASAN \\ Hasil}

Uji coba lapangan juga dilakukan di SMP Negeri 6 Pematangasiantar.uji coba lapangan dilakukan terhadap kelas VII yang terdiri dari 60 siswa dari dua kelas yakni kelas VII-1 sebanyak 30 siswa dan kelas VII-2 sebanyak 30 siswa.uji coba lapangan akan menghasilkan data- data yang akan mengukur kelayakan dari produk yang dikembangkan, serta mengetahui manfaat produk bagi pemakaianya.hasil penilaian media pembelajaran terhadap aspek kualitas teknis atau tampilan secara keseluruhan dalam kriteria sangat baik,hal ini terangkum pada tabel 2 berikut:

Tabel 2. Skor Penilaian Media Pembelajaran Mata Pelajaran Seni Budaya Pada Uji Coba Lapangan Di SMP Negeri 6 Pematangsiantar Tentang Kualitas Materi Pembelajaran

\begin{tabular}{|c|c|c|c|c|c|c|c|c|}
\hline \multirow{3}{*}{$\mathrm{No}$} & \multirow{3}{*}{ Indikator penilaian } & & & & & & & \\
\hline & & \multicolumn{5}{|c|}{ Skor } & \multirow{2}{*}{ Rata- rata } & \multirow{2}{*}{ Kriteria } \\
\hline & & 1 & 2 & 3 & 4 & 5 & & \\
\hline 1 & Kesesuaian materi & & & & 6 & 54 & $98,00 \%$ & Sangat Baik \\
\hline 2 & Kejelasan petunjuk belajar & & & & 4 & 56 & $98,67 \%$ & Sangat Baik \\
\hline 3 & $\begin{array}{l}\text { Kemudahan memahami kalimat } \\
\text { pada teks }\end{array}$ & & & & 3 & 57 & $99,00 \%$ & Sangat Baik \\
\hline 4 & $\begin{array}{l}\text { Kemudahan memahami } \\
\text { pembelajaran }\end{array}$ & & & & 7 & 53 & $97,67 \%$ & Sangat Baik \\
\hline 5 & Ketepatan urutan penyajian & & & & 4 & 56 & $98,67 \%$ & Sangat Baik \\
\hline 6 & Kecukupan latihan & & & & 13 & 47 & $95,67 \%$ & Sangat Baik \\
\hline 7 & Kejelasan umpan balik & & & & 2 & 58 & $99,34 \%$ & Sangat Baik \\
\hline 8 & Bantuan belajar dengan program & & & & 2 & 58 & $99,34 \%$ & Sangat Baik \\
\hline & Rata- rata & & & & & & $98,30 \%$ & Sangat Baik \\
\hline
\end{tabular}


Tabel 3. Skor Penilaian Media Pembelajaran Mata Pelajaran Seni Budaya Pada Uji Coba lapangan Di SMP Negeri 6 Pematangsiantar Tentang Kualitas Teknis Atau Tampilan

\begin{tabular}{|c|c|c|c|c|c|c|c|c|}
\hline \multirow{2}{*}{ No } & \multirow{2}{*}{ Indikator penilaian } & \multicolumn{5}{|c|}{ Skor } & \multirow{2}{*}{ Rata- rata } & \multirow{2}{*}{ Kriteria } \\
\hline & & 1 & 2 & 3 & 4 & 5 & & \\
\hline 1 & Keindahan tampilan layar & & & & 2 & 58 & $99,34 \%$ & Sangat Baik \\
\hline 2 & Keterbacaan teks & & & & & 60 & $100,00 \%$ & Sangat Baik \\
\hline 3 & $\begin{array}{l}\text { Kualitas video, gambar, dan } \\
\text { animasi }\end{array}$ & & & & 5 & 55 & $97,34 \%$ & Sangat Baik \\
\hline 4 & Komposisi warna & & & & 11 & 49 & $96,34 \%$ & Sangat Baik \\
\hline 5 & Navigasi & & & & 9 & 51 & $97,00 \%$ & Sangat Baik \\
\hline 6 & Daya dukung musik & & & & 7 & 53 & $97,66 \%$ & Sangat Baik \\
\hline 7 & Interaksi & & & & 2 & 58 & $99,34 \%$ & Sangat Baik \\
\hline & Rata- & & & & & & $98,14 \%$ & Sangat Baik \\
\hline
\end{tabular}

Tabel 4. Persentase Rata- Rata Hasil Penilaian media pembelajaran interaktif Terhadap Media Pembelajaran Mata Pelajaran Seni Budaya Oleh Ahli Materi

\begin{tabular}{|l|l|c|c|}
\hline No & Kategorisasi & Persentase rata-rata & Kriteria \\
\hline 1 & Aspek materi pembelajaran & $90,00 \%$ & Sangat Baik \\
\hline 2 & Aspek strategi pembelajaran & $88,33 \%$ & Sangat Baik \\
\hline 3 & Aspek sistem penyampaian pembelajaran & $90,00 \%$ & Sangat Baik \\
\hline \multicolumn{2}{|c|}{ Rata- rata } & $89,44 \%$ & Sangat Baik \\
\hline
\end{tabular}

Tabel 5. Persentase Rata- Rata Hasil Penilaian Terhadap Media Pembelajaran Mata Pelajaran Seni Budaya Oleh Ahli Desain Pembelajaran

\begin{tabular}{|l|l|c|c|}
\hline No & Kategorisasi & Persentase rata-rata & Kriteria \\
\hline 1 & Aspek desain pembelajaran & $95,00 \%$ & Sangat Baik \\
\hline 2 & Aspek desain informasi & $91,25 \%$ & Sangat Baik \\
\hline 3 & Kualitas desain interaksi & $82,50 \%$ & Sangat Baik \\
\hline 4 & Kualitas desain presentasi & $91,25 \%$ & Sangat Baik \\
\hline \multicolumn{2}{|c|}{ Rata- rata } & $\mathbf{9 0 , 0 0 \% \%}$ & Sangat Baik \\
\hline
\end{tabular}

Tabel 6. Persentase Rata- Rata Hasil Penilaian Terhadap Media Pembelajaran Mata Pelajaran Seni Budaya Oleh Ahli Rekayasa Perangkat Lunak

\begin{tabular}{|l|l|c|l|}
\hline No & Kategorisasi & Persentase rata-rata & Kriteria \\
\hline 1 & Aspek pemprograman & $86,25 \%$ & Sangat Baik \\
\hline 2 & Aspek kualitas teknis atau tampilan & $87,14 \%$ & Sangat Baik \\
\hline \multicolumn{2}{|l}{ Rata- rata } & $\mathbf{8 6 , 6 9 \%}$ & Sangat Baik \\
\hline
\end{tabular}

Tabel 7. Persentase Rata- Rata Hasil Penilaian Terhadap Media Pembelajaran Mata Pelajaran Seni Budaya Pada Uji Perorangan

\begin{tabular}{|l|l|c|c|}
\hline No & Kategorisasi & Persentase rata-rata & Kriteria \\
\hline 1 & Aspek kualitas materi pembelajaran & $91,67 \%$ & Sangat Baik \\
\hline 2 & Aspek kualitas teknis atau tampilan & $93,33 \%$ & Sangat Baik \\
\hline \multicolumn{2}{|c|}{ Rata- rata } & $\mathbf{9 2 , 5 0 \%}$ & Sangat Baik \\
\hline
\end{tabular}

Tabel 8. Persentase Rata- Rata Dari Hasil Penilaian Terhadap Media Pembelajaran Interaktif Pada Pembelajaran Seni Budaya Terhadap Uji Coba Kelompok Kecil

\begin{tabular}{|l|c|c|c|}
\hline No & Kategorisasi & Persentase rata-rata & Kriteria \\
\hline 1 & Aspek kualitas materi pembelajaran & $94,72 \%$ & Sangat Baik \\
\hline 2 & Aspek kualitas teknis atau tampilan & $95,24 \%$ & Sangat Baik \\
\hline \multicolumn{2}{|c|}{ Rata- rata } & $\mathbf{9 4 , 9 8 \%}$ & Sangat Baik \\
\hline
\end{tabular}


Tabel 9. Persentase Rata- Rata Hasil Penilaian Terhadap Media Pembelajaran Mata Pelajaran Seni Budaya Pada Uji Coba Lapangan

\begin{tabular}{|l|c|c|c|}
\hline No & Kategorisasi & Persentase rata-rata & Kriteria \\
\hline 1 & Aspek kualitas materi pembelajaran & $98,30 \%$ & Sangat Baik \\
\hline 2 & Aspek kualitas teknis atau tampilan & $98,14 \%$ & Sangat Baik \\
\hline Rata- rata & $\mathbf{9 8 , 2 2} \%$ & Sangat Baik \\
\hline
\end{tabular}

Tabel 10. Rangkuman Persentase Rata- Rata Hasil Penilaian Media Pembelajaran Interaktif Mata Pelajaran Seni Budaya Oleh Para Ahli

\begin{tabular}{|c|l|c|c|}
\hline No & \multicolumn{1}{|c|}{ Para ahli } & Persentase & Kriteria \\
\hline 1 & Materi pembelajaran & $89,44 \%$ & Sangat baik \\
\hline 2 & Desain pembelajaran & $90,00 \%$ & Sangat baik \\
\hline 3 & Ahli rakyasa perangkat lunak & $86,69 \%$ & Sangat baik \\
\hline \multicolumn{2}{|c|}{ Rata- rata } & $88,71 \%$ & Sangat baik \\
\hline
\end{tabular}

Tabel 11. Rangkuman Persentase Rata- Rata Hasil Penilaian Media Pembelajaran Interaktif Mata Pelajaran Seni Budaya Oleh Siswa

\begin{tabular}{|c|l|c|c|}
\hline No & \multicolumn{1}{|c|}{ Para Ahli } & Persentase & Kriteria \\
\hline 1 & Uji coba perorangan & $92,50 \%$ & Sangat Baik \\
\hline 2 & Uji coba kelompok kecil & $94,98 \%$ & Sangat Baik \\
\hline 3 & Uji coba lapangan & $98,22 \%$ & Sangat Baik \\
\hline \multicolumn{2}{|c|}{ Rata- rata } & $95,23 \%$ & Sangat Baik \\
\hline
\end{tabular}

\section{Uji Efektifitas Produk Nilai pretes}

Uji normalitas dilakukan untuk mencari kenormalan dari sampel yang diteliti.Uji normalitas data pre- test menggunakan uji liliefors (Sujana, 2005:466) dari hasil uji coba normalitas pada kelas yang menggunakan buku

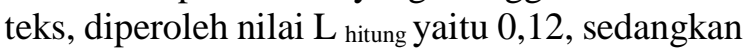
$\mathrm{L}$ tabel pada taraf signifikansi 0,05 dan $\mathrm{n}=30$ adalah 0,161.hal ini menunjukkan bahwa $\mathrm{L}_{\text {hitung }}$ $<\mathrm{L}$ tabel, artinya sampel berasal dari populasi yang berdistribusi normal. Sedangkan uji normalitas nilai pretes untuk kelas yang menggunakan media interaktifdiperoleh nilai $\mathrm{L}$ hitung $=0,09$, sedangkan $\mathrm{L}$ tabel pada taraf signifikansi 0,05 dan $n=30 . L_{\text {tabel }}$ adalah 0,16 , hal ini meninjukkan bahwa $\mathrm{L}$ hitung $<\mathrm{L}$ tabel, maka dapat disimpulkan bahwa sampel berasal dari populasi yang berdistribusi normal.

\section{Nilai Postes}

Setelah dialkukan perhitungan bahwa, maka pada kelas yang menggunakan media interaktif diperoleh nilai $\mathrm{L}$ hitung yaitu 0,155 , sedangkan $\mathrm{L}_{\text {tabel }}$ pada taraf signifikansi 0,05 dan $\mathrm{n}=30$ adalah 0,161 .hal ini menunjukkan bahwa $\mathrm{L}$ hitung $<\mathrm{L}$ tabel, artinya sampel berasal dari populasi yang berdistribusi normal. Sedangkan uji normalitas nilai postes untuk kelas yang menggunakan media buku teks diperoleh nilai $\mathrm{L}$ hitung $=0,27$, sedangkan $\mathrm{L}$ tabel pada taraf signifikansi 0,05 dan $n=30 L_{\text {tabel }}$ adalah 0,16 , hal ini meninjukkan bahwa $\mathrm{L}$ hitung $<\mathrm{L}$ tabel, maka dapat disimpulkan bahwa sampel berasal dari populasi yang berdistribusi normal. Berdasrkan uji normalitas kedua kelas diatas , maka dapat disimpulkan bahwa seluruh populasi data penelitian berditribusi normal.(perhitungan selengkapnya dapat dilihat pada lampiran)

\section{Uji Homogenitas Data}

Untuk menguji homogenitas nilai pretes diperoleh nilai varians pretes untuk kelas yang menggunakan media interaktif adalah 87,47 dan varians pada kelas menggunakan buku teks adalah 92,8 dari niali varians ini diperoleh $\mathrm{F}_{\text {hitung }}$ $=1,06$ nilai $\mathrm{F}_{\text {tabel }}=$ pada taraf signifikansi maka 0,05 dan $\mathrm{n}=30$ dengan $\mathrm{dk}$ pembilang $30 \mathrm{dan} \mathrm{dk}$ penyebut 2 adalah 3,32, maka $F_{\text {hitung }}<F_{\text {tabel }}$ yaitu $1,12<3,32$, sehingga dapat disimpulkan bahwa data dari nilai pretes pada kedua kelas tersebut mempunyai varians yang sama atau homogen. Hal yang sama dilakukan juga pada nilai postes untuk kelas yang menggunakan media interaktif adalah 41,87 dan varians pada kelas yang menggunakan buku teks adalah 44,97 sehingga diperoleh $\mathrm{F}$ hitung $=1,07$ nilai $\mathrm{F}$ tabel $=$ pada taraf signifikansi maka 0,05 dan $n=30$ dengan $d k$ pembilang 30 dan dk penyebut 2 adalah 
3,32, maka $\mathrm{F}$ hitung $<\mathrm{F}$ tabel yaitu $1,05<3,32$, sehingga dapat disimpulkan bahwa data dari nilai postes pada kedua kelas tersebut mempunyai varians yang sama atau homogen.

Uji Hipotesis

Hipotesis yang diajukan dalam penelitian ini adalah mengetahui keefektifan menggunakan media interaktif dibandingkan dengan penggunaan buku teks terhadap peningkatan hasil belajar siswa pada mata pelajaran seni budaya.Namun untuk menilai keefektifan media , maka perlu mengetahui perbedaan hasil belajar yang diajar dengan menggunakan media pembelajaran interaktif dengan hasil belajar dengan menggunakan buku teks. Untuk menguji hal ini digunakan uji- t.

Keefektifan menggunakan media pembelajaran interaktif adalah sebagai berikut:

$\mathrm{X}_{1}=\frac{\text { Jumlah Skor Yang Diperoleh }}{\text { Jumlah Skor Total }} X 100 \%$

$X_{1} \frac{2430}{3000} 100 \%$

$X_{1}=81,00 \%$

Sedangkan efektifitas pembelajaran menggunakan buku teks adalah sebagai berikut: $\mathrm{X}_{2}=\frac{\text { Jumlah Skor Yang Diperoleh }}{\text { Jumlah Skor Total }} X 100 \%$

$X_{2} \frac{2125}{3000} 100 \%$

$X_{2}=70,83 \%$

Dari hasil perhitungan efektifitas diatas, dapat disimpulkan bahwa hasil belajar siswa yang diajar dengan menggunakan media pembelajaran interaktif $81 \%$ atau lebih tinggi dari hasil belajar siswa yang diajar dengan menggunakan dengan buku teks $70,83 \%$. Dari hasil pengolahan data pada uji t diperoleh $t_{\text {hitung }}$ sebesar 1,71 sedangkan $t_{\text {tabel }}$ pada taraf $\alpha=0,05$ dengan dk 60 adalah 1,61 maka $\mathrm{t}_{\text {hitung }}>\mathrm{t}_{\text {tabel }}$ atau $1,71>1,66$. Hasil uji t yang diperoleh dikatakan signifikan( hipotesis diterima) jika harga $t_{\text {hitung }}>$ $t_{\text {tabel }}$ pada taraf signifikansi 0,05. Berdasarkan hasil data maka kesimpulanya adalah terdapat perbedaan hasil belajar siswa yang diajar dengan menggunakan media pembelajaran interaktif dengan hasil belajar siswa yang diajar dengan menggunakan dengan buku teks pada taraf signifikan 0,05 (5\%)

\section{Pembahasan}

Penelitian pengembangan produk ini dilakukan untuk menghasilkan suatu produk berupa media pembelajaran interaktif pada mata pelajaran seni budaya untuk siswa kelas VII semester genap yang bertujuan untuk meningkatkan proses belajar dan kompetensi siswa.oleh sebab itu produk pengembangan media pembelajaran interaktif yang telah dikembangkan dengan memperhatikan aspek pembelajaran dan media sebagai prinsip desain pesan pembelajaran.dimana proses pengerjaanya diawali dengan (1) perencanaan kebutuhan awal dengan melakukan studi pendahuluan yang meliputi observasi, wawancara dan studi pustaka.dari observasi tersebut diperoleh gambaran bahwa pembelajaran yang dilakukan di kelas cenderung menggunakan pendekatan tradisional meskipun sebenarnya tersedia fasilitas belajar yang cukup memadai seperti komputer dan infokus,(2) setelah itu,mendesain produk pembelajaran untuk menghasilkan produk awal bahan ajar pembelajaran, (3) mengembangkan bahan ajar, kegiatan ini meliputi pembuatan storyboard yang dilanjutkan dengan pengumpulan bahan- bahan pendukung seperti foto, video, audio, animasi, dan image yang diperlukan untuk melengkapi bentuk media,(4) implementasi yaitu kegiatan pemograman bahan ajar dengan bentuk media dengan menggunakan software CS6 yang dilanjutkan dengan burning/ proses pencetakan media dalam bentuk CD pembelajaran.(5) melakukan revisi, kegiatan ini meliputi evaluasi produk untuk mengetahui kelebihan dan kekurangan serta kelemahan mengenai kualitas isi dan desain yang dilakukan oleh para ahli materi,disain dan ahli rekayasa perangkat lunak,(6) hasil revisi selanjutnya diuji cobakan kepada siswa melalui uji coba perorangan, uji coba kelompok kecil dan uji coba lapangan sehingga dihasilkan media pembelajaran yang layak digunakan sesuai dengan karakteristik bidang studi dan siswa sebagai pengguna.hal ini sejalan dengan pendapat Borg\& Gall( 1983:772) pada buku Education research; an introduction yang mengemukakan bahwa penelitian pengeembangan adalah penelitian yang berorientasi untuk mengembangkan dan memvalidasi produk- produk yang dipergunakan dalam pendidikan.

Manfaat yang diperoleh dari penggunaan media pembelajaran interaktif adalah konsep yang disajikan mudah dipelajari,dipahami dan sistematis.media pembelajaran interaktif memberi kesempatan pada siswa untuk belajar sesuai dengan kecepatan masing- masing, mandiri dan tidak 
menimbulkan kebosanan karena dilemhkapi dengan ganmbar- gambar, video dan animasi serta soal latihan yang bervariasi. adanya pengulangan yang harus dilakukan saat jawaban salah menjadikan siswa lebih memahami materi. Media pembelajaran interaktif ini juga dapat digunakan sebagai alternative media pembelajaran secara klasikal maupun individual.

Aspek yang direvisi dan disempurnakan berdasarkan analisis data dan uji coba serta masukan dari ahli materi, ahli desain pembelajaran, dan ahli rekayasa perangkat lunak dan siswa sebagai pengguna media interaktif ini, bertujuan untuk menggali beberapa aspek yang lazim dalam proses pengembangan suatu produk.variabel- variabel media pembelajaran memiliki nilai rata- rata sangat baik.adapun variabel media pembelajaran yang dinilai meliputi kelayakan isi, penyajian, kebahasaan, pemprograman, dan kegrafikan. Dalam penemuan terdahulu lignin (2012:131) menyatakan bahwa media pembelajaran interaktif dengan menggunakan software macromedia lebih efektif digunakan dengan hasil 81 dan 70,83 dengan menggunakan buku teks.

Penggunaan media interaktif dalam pembelajaran seni budaya memungkinkan siswa untuk berinteraksi langsung dan melakukan konterol langsung pada sumber informasi, sehingga siswa dapat mengendalikan dan memperoleh apa yang menjadi kebutuhanya misalya membaca sumber- sumber untuk materi menggambar bentuk benda silindris yang mana telah disediakan dalam media pembelajaran interaktif.siswa juga dapat mengerkjakan soalsoal latihan yang telah dilengkapi dengan balikan dan pembahasan sehingga siswa dapat mengetahui kesalahan yang telah dilakukan dalam mengerjakan soal- soal latihan tersebut.media pembelajaran interaktif juga dilengkapi denagn rangkuman yang dapat membantu siswa memperolah ringkasan materi pelajaran yang dipaparkan.

Pembelajaran dengan medi interaktif juga memungkinkan guru bebas melakukan interaksi denagn siswa sehingga pembelajaran tersebut bersifat interaktif yang membuat pembelajaran terfokus pada informasi yang sedang dipelajari.hal ini berbeda dengan pembelajaran yang menggunakan buku teks, siswa tidak berinterkasi langsung pada sumber informasi dan pembelajaran yang didominasi oleh guru yang menjadikan informasi secara linier atau satu arah.hal ini terjadi karena pada pembelajaran melalui buku teks tidak dapat memperoleh balikan dari soal- soal latihan yang dikerjakan.

Pembelajaran dengan menggunakan media pembelajaran interaktif memiliki tingkat keefektifan yang lebih tinggi dari pada penggunaan buku teks. Hal ini dapat dilihat dari hasil nilai rata-rata seni budaya siswa yang diajar dengan media pembelajaran interaktif yaitu sebesar 81 ,sedangkan nilai rata-rata seni budaya siswa yang diajar dengan media buku teks yaitu sebesar 70,83 dari data ini membuktikan bahwa penggunaan media pembelajaran interaktif lebih baik dalam meningkatkan pengetahuan siswa dalam pembelajaran seni budaya dari pada penggunaan buku teks.

\section{PENUTUP}

Produk media pembelajaran interaktif pada pembelajaran seni budaya yang dikembangkan menunjukkan bahwa :

a. Hasil validasi dari ahli materi terhadap multimedia pembelajaran pada mata pelajaran seni budaya yang dikembangkan bahwa : (1) kulitas materi pembelajaran dinilai sangat baik, (2) kulitas strategi pembelajaran dinilai sangat baik, (3) kualitas sistem penyampaian pembelajaran dinilai sangat baik. Dengan demikian multimedia pembelajaran secara keseluruhan dalam kategori "Sangat Baik".

b. Hasil validasi dari desain pembelajaran terhadap multimedia pembelajaran pada mata pelajaran seni budaya yang dikembangkan menunjukkan bahwa : (1) kualitas Desain pembelajaran dinilai sangat baik, (2) kualitas desain informasi dinilai sangat baik, (3) kulitas desain interaksi dinilai sangat baik, (4) kulitas desain presentasi dinilai sangat baik. Dengan demikian penilaian ahli desain pembelajaran terhadap media pembelajaran secara keseluruhan dalam kategori "Sangat Baik" sehingga layak digunakan dalam proses pembelajaran.

c. Hasil validasi dari ahli rekayasa perangkat lunak pada mata pelajaran seni budaya yang dikembangkan menunjukkan bahwa : (1) kualitas aspek pemograman dinilai sangat baik, (2) kualitas teknis atau tampilan dinilai sangat baik. Dengan demikian penilaian ahli rekayasa perangkat lunak yang dikembangkan secara keseluruhan dalam 
kategori "Sangat Baik" sehingga layak digunakan dalam proses pembelajaran.

d. Hasil uji coba produk pada uji coba perorangan menunjukkan bahwa untuk kuliatas materi pembelajaran dinilai sangat baik, sedangkan untuk kualitas teknis atau tampilan dinilai sangat baik. Dengan demikian hasil tanggapan siswa terhadap media pemnbelajaran yang dikembangkan secara keseluruhan dinilai "Sangat Baik" sehingga layak digunakan dalam proses pembelajaran.

e. Hasil uji coba produk pada uji coba kelompok kecil menunjukkan bahwa untuk kulaitas materi pembelajaran dinilai sangat baik, sedangkan untuk kulaitas teknis atau tampilan dinilai sangat baik. Dengan demikian hasil tanggapan siswa terhadap media pembelajaran yang dikembangkan secara keseluruhan dinilai "Sangat Baik" sehingga layak digunakan dalam proses pembelajaran.

f. Hasil uji coba produk pada uji coba lapangan menunjukkan bahwa untuk kualitas materi pembelajaran dinilai sangat baik, sedangkan untuk kualiats teknis atau tampilan dinilai sangat baik. Dengan demikian hasil tanggapansiswa pada uji coba lapangan terhadap multimedia pembelajaran yang dikembangkan secara keseluruhan dinilai "Sangat baik" sehingga layak diguakan dalam proses pembelajaran.

Secara keseluruhan media pembelajaran yang dihasilkan layak untuk diguanakan sebagai media pembelajaran pada mata pelajaran seni budaya, hal ini ditunjukkan dari hasil Rangkuman Persentase Rata-rata Hasil Penilaian Terhadap Mata Pelajaran Seni Budaya Dalam Kriteria "Sangat Baik". Penggunaan media pembelajaran interaktif lebih efektif dibandingakan dengan penggunaan buku teks.

a. Penggunaan media pembelajaran interaktif lebih efektif meningkatkan hasil belajar, hal ini ditunjukkan oleh hasil belajar yang menggunakan media pembelajaran interaktif memperoleh nilai rata-rata 81 Dibandingkan dengan kelas yang diajar dengan menggunakan buku teks memperoleh nilai rata-rata 70,83 .

b. Terdapat perbedaan hasil belajar siswa yang diajar dengan media pembelajaran interaktif dibandingkan dengan siswa yang diajar dengan buku teks, dengan $t_{\text {hitung }}$ sebesar 1,71 sedangkan $\mathrm{t}_{\text {tabel }}$ pada taraf $\alpha=0,05$ dengan $\mathrm{dk}$ 60 adalah1,71 Atau thitung $>t_{\text {tabel }} 1,66$

\section{DAFTAR PUSTAKA}

Ahmadi, Abu. 2003. Strategi Belajar Mengajar. Bandung. CV Pustaka Setia

Anderson, Krathwol. 2010. Kerangka Landasan Untuk Pembelajaran ,Pengajaran Dan Assesmen (Revisi Taksonomi Bloom). Yogyakarta. Pustaka Belajar

Apriyatno, Veri. 2004. Cara Menggambar Dengan Pensil. Jakarta. Kawan Pustaka

Arikunto, Suharsimi. 2006. Prosedur Penelitian Suatu Pendekatan Praktik. Jakarta. Rhineka Cipta

Borg,W \& V Gall,M.D. 1983. Educational Research An Introduction. New York \& London: Longman

Dahar, R. W. 2006. Teori-Teori Belajar. Jakarta: Erlangga

D.K Francis .Ching.2002. Menggambar Suatu Proses Kreatif Terjemahan Paulus Hanoto; Adjie. Jakarta. Erlangga

Dick, W, Carey, L. 2005. The systemic design of Instruction. United States of America: Scott Foresman and Company

Effendi, Onong. Uchjana. 2003. Ilmu,Teori dan Filsafat Komunikasi. Bandung. Citra Aditya Bakti.

Hamid, A. Jurnal Teknologi Pendidikan Volume 6 No 2.Medan. Universitas Negeri Medan

Handoyo,B. 2003. Aplikasi Media Untuk Pembelajaran. Malang. Geo Spektrum

Istiono, Wirawan. 2008. Education Game With Flash CS6. Jakarta. Elex Media Komputindo

Hakim,Lukmanul.2004. Cara Ampuh Menguasai Macromedia Flash . Jakarata. Jakarta: Elex Media Komputindo

Kustiono 2010. Media Pembelajaran Interaktif, Nilai Edukatif, Klasifikasi, Praktek Pemanfaatan Dan Pengembangan . Semarang: Unnes Press

Madcoms. 2009. Animasi Cantik Dengan Adobe Flash. Yogyakarta. Penerbit Andi

Miarso. 2004. Menyemai Benih Teknologi Pendidikan. Jakarta. Prenada Media.

Nurdin,syafruddin.2005.Guru Professional Dan Implementasi Kurikulum. Cipuat. Quantum Teaching

Nusantara,Yayat. 2004. Kesenian SMA Untuk Kelas X. Jakarta. Erlangga 
Oetomo, Priyogutomo. 2004. Kajian Terhadap Model E-Media Dalam Pembangunan Sistem E-Education. Seminar Nasional. Jakarta

Pratt,D.1980. Curriculum Design And Development .San Diago. Harcoutt Brace Jovanovich Publisher

Rasjoyo. 1996. Pendidikan Seni Rupa. Jakarta. Erlangga

Rosifah, Hanung. 2007. Menggambar Bentuk. Jakarta.Raja Grafindo Persada

Romiszowski. 1988. The Selection and Use of Instructional Media. United States: Nicholas Publishing

Reigeluth,C.M.D.Instructional Design Theories And Models: An Overvious OF Their Current Status. London: Lawrer Erlbaum Associates,Publisher

Regelski, Thomas,A.1981.Teaching General Art Action Learning For Middle And Secondary Schools. Newyork. Schirmer Books

Sadiman, Arif, dkk. 2011. Media Pendidikan, Pengertian, Pengembangan dan Pemanfaatannya. Jakarta: Putekkom Dikbud

Setiyawati.2006. Tujuan Pendidikan. Jakarta: Raja Grafindo Persada

Sulastianto, Harry.2011. Apresiasi Dan Kreasi Pendidikan Seni Untuk SMP. Bandung. Grafindo Media Pratama
Sukmadinata, Nana S. 2008. Metode Penelitian Pendidikan. Bandung: Rosdakarya

Sugihartono, dkk. 2007. Psikologi Pendidikan. Yogyakarta. UNY Press

Snelbecker, G. E. 1984. Learning Theory, Instructional Theory; And Psycho Educational Design. Newyork: MC Grow-Hill Book

Sumiati,Asra. 2009. Metode Pembelajaran. Bandung: CV Wacana Prima

Sutopo. A. 2003. Multimedia Interaktif Dengan Flash. Yokyakarta: Graha Ilmu

Suryabrata, Sumadi.2012. Psikologi Pendidikan. Jakarta: Raja Grafindo Persada

Wardhani.2005. Psikologi Belajar. Bandung: Sinar Baru Algesindo

W.S,Winkel. 2004. Bimbingan dan Konseling di Institusi Pendidikan. Yogyakarta: Media Abadi

W. S, Winkel. 2007. Psikologi Pengajaran. Jakarta: Gramedia

Winataputra. 2008. Teori Belajar Dan Pembelajaran.jakarta. Universitas Terbuka Jakarta

Yudhi Munadi. 2008. Media Pembelajaran. Yogyakarta: Media Abadi

Zamroni. 2000. Paradigma Pendidikan Masa Depan. Yogyakarta.Bigraf Publissing 